\title{
Lise öğrencilerinde kendilik imgesinin okul başarısına etkisi
}

\author{
Mehtap YILDIRIM*
}

Öz

$\mathrm{Bu}$ çalışmanın amac1, lise öğrencilerinin ergenlik dönemi süresince geliştirdikleri kendilik imgesinin okul başarısına bir etkisinin olup olmadığını tespit etmektir. Araştırma, nicel araştırma modellerinden betimsel çalışma modeliyle gerçekleştirilmiştir. Bu kesitsel çalışmaya, Zonguldak ili Devrek ilçesindeki iki farklı lisede öğrenim gören 123 öğrenci dâhil edilmiștir. Katılımcılara araştırmacı tarafından hazırlanan sosyodemografik veri anketi ve Offer Kendilik İmgesi Anketi uygulanmıştır. Not ortalamalarının cinsiyetlere göre karşılaştırılması t-testi; sınıf düzeyine göre karşılaştırılması ise Tek Yönlü Varyans analizi ile yapılmıştır. Sürekli değişkenlerin not ortalaması ile ilişkisi Pearson Momentler Çarpımı Korelasyon analiziyle, not ortalaması ile anlamlı olarak ilişkili bulunan değişkenler ise Çoklu Doğrusal Regresyon analizi ile incelenmiştir. Çalışmanın bulgularına göre cinsiyetler açısından yapılan karşılaştırmada kız öğrencilerin meslek ve eğitim hedefleri ile okul başarılarının erkeklere oranla daha yüksek olduğu tespit edilmiştir. Kendilik imgesi faktörlerinden "Meslek ve eğitim hedefleri (ME)" ve "Bireysel değerler (BD)" ile okul başarısı arasında anlamlı ve doğrusal bir ilişki olduğu görülmüştür. Meslek ve eğitim hedeflerinin ise diğer değişkenlerden bağımsız olarak okul başarısını önemli ölçüde etkilediği saptanmıştır. Lise öğrencilerinde okul başarısını etkilediği ortaya konan kendilik imgesinin meslek eğitim hedefleri boyutu, okul başarısını artırmada üzerinde çalışma yapılabilecek bir konudur.

Anahtar kelimeler: Kendilik imgesi, lise öğrencileri, ders başarısı

\section{The effect of self-image on school success among high school students}

\begin{abstract}
This study aims to investigate whether the self-image of high school students, which they develop during the adolescence period, has an effect on their school success. An experimental study with quantitative research methods was applied. 123 students from two different high schools in Devrek, a town in the city of Zonguldak, were included to this sectional study. Offer Self Image Questionnaire and the socio-demographic information form that had been prepared by
\end{abstract}

\footnotetext{
* Doktora Öğrencisi, Abant İzzet Baysal Üniversitesi, Eğitim Bilimleri Enstitüsü, mehtapcanan1983@gmail.com
} 
the researcher, were administered to the participants. The mean scores were compared via t-test according to the gender and via One Way ANOVA according to the grade. The relationship of constant variables with mean scores was investigated by Pearson Momentum Correlation analysis and the variables which were found to be significantly related by Multible Lineer Regression analaysis. In a comparison with regard to the gender, female students were found to have higher school success and education goals than the male students. Among the factors of self-image, "Professional and educational targets (ME)" and "Individual values (BD)" showed a significant and linear relation with the school success. Moreover "Professional and educational targets" was found to considerably affect the school success, independently from other variables. According to these data, we suggest that particularly "professional and educational targets" aspect of the selfimage, provides an area to work on for the improvement of school success among high school students.

Keywords: Self-image, high school students, school success

\section{Giriş}

Ergenlik dönemi bireysel gelişim değişik yönlerden ele alınabilir. Yapılan çalışmalarda ergenliğe, fizyolojik gelişim, toplumsal etkiler, ekonomik düzey, duygusal gelişim ve aile içi iletişim gibi faktörlerin şekil verdiği ve kişisel karakterlerin ergenlik döneminde belirginleştiği vurgulanmıştır (Çetin ve diğerleri, 2010; Çetin ve Ulay, 2011). Ergenlik ayrıca, bireyin davranış biçimini belirleyen kavramların, değerlerin, amaçların ve ideallerin dinamik organizasyonu olarak da tanımlanabilir.

Benlik ise bireyin kendiliğini ve öz oluşunu ifade ettiği gibi, içinde yaşadığ diğer benliklerden farklılaştıran temel ve belirgin özelliklerinin dinamik bir biçimde birey tarafından soyutlanması olarak tanımlanabilir (Özoğlu, 1976; Şekercioğlu ve Güzeller, 2012). Benlik kavramını, kendilik imgesi ve kendini algılama öğelerinin birleşmesi ile oluşan bir bütün olarak değerlendirenler de vardır (Bogenç, 1998). Burada kendilik imgesi ise, bireyin özüne karş1 olan tutumudur (Burns, 1976). Bu tutum, benlikle ilgili gerçeklerin, düşüncelerin ve değerlerin yanı sıra, öze karşı olumlu ve olumsuz yönelimleri de içermektedir (Gender ve Gardiner, 1993). Damon ve Hart (1988) ergenlik dönemindeki benlik gelişimini bireyin kendini fiziksel bir obje olmaktan çok duygusal, psikolojik yönünün olduğunu fark etmesiyle ilerleyen ve benliğin bu yönlerinin kişinin kendi benlik algısı ve diğerlerinin onu algılamasıyla bağlantılı olarak organize olmasıyla açıklamıştır.

Benlik imgesi, bireylerin kendileriyle ilgili öz değerlendirmelerini ve duygusal ve fiziksel olarak nasıl bir kişi olduklarıyla ilgili inançlarını kapsayan geniş bir kavramdır (Paglieri, 2012). Ergenlerde fiziksel durum, dış görünüş, aile ve arkadaşlarla olan etkileşimler ve sosyo-kültürel yapı kendilik imgesinin oluşumunda önemli roller almaktadır (Çetin ve diğerleri, 2010). Ergenlerin benlik kavramları bedenlerine ilişkin sahip oldukları algılarla yakından ilişkilidir. Ergen fiziksel olarak değiştikçe, bedenini kendisi gibi hissedememekte, yeni bir fiziksel benlik kavramı oluşturmak durumunda kalmaktadır (Adams, 1995). Bireyin görünüşünün, hem 
erkekler, hem de kadınlarda benlik kavramının önemli bir belirleyicisi olduğunu öne süren çok sayıda araştırma bulunmaktadır (Offer ve diğerleri, 1981; Offer ve diğerleri, 1984).

Benlik oluşumunda aile kavramı da önemli rol oynamaktadır. Ergenlik döneminde ailenin ve toplumun değerlerini içselleştiren birey, standartlarını oluşturmaya başlayarak, değerlendirmelerinde bu standartları temel almaktadır. Bu dönemde, bireyler fiziksel özellikleri, yetenekleri, üstünlükleri gibi yönlerini ifade etmeyi öğrendikleri gibi kendilerini değerlendirmeye başlarlar. Bireyin aile ile olan bağllı̆̆ı, akademik açıdan başarılı ya da başarısız hissetmesi, sosyal çevreye uyumu, mesleki ve eğitimsel hedefleri gibi faktörler onun kendisine ilişkin görüş oluşturmasına etki eder (Offer ve diğerleri, 1992). Ergenin zamanla sahip olduğu özelliklerin farkına daha çok varmasıyla, bu süreç, yani kendilik imgesinin oluşumu hız kazanır (Demiriz ve Öğretir, 2007). Kuzgun (1985) çalışmasında, ana-babalar ve ergenler arasındaki demokratik ilişkilerin özdeşleşmeyi ve yakınlığı destekleyerek, ergenlerin, öz-güvenli, uyumlu, yaratıcı ve disiplinli bireyler olmalarını sağlayan kendilik imgeleri geliştirdiklerini ortaya koymuştur.

Kültür ile benlik ilişkisine bakıldığında, benliği oluşturan bireyin sahip olduğu kimliğin, kültürün bir ürünü olduğu anlaşılmaktadır (Hauser ve Shapiro, 1973). Hauser (1976)’a göre kendilik, kişinin sahip olduğu toplumsal kimliğin bir parçasıdır ve kişinin benlik kavramı buna bağlı olarak oluşmaktadır.

Ergenlerde okul başarısı ve benlik algısı arasındaki ilişki incelendiğinde ise farklı bulgular ortaya çıkmaktadır. Örneğin, Loeb ve Jay (1987) fen liselerinde okuyan başarılı öğrencilerin diğerlerine göre daha olumlu benlik algılarına sahip olduklarını belirtmiştir. Zeidner ve Schleyer (1998) bu durumun aksine fen lisesi gibi başarı durumu homojen olan sinıflardaki öğrencilere göre heterojen olan diğer okullardaki başarılı öğrencilerin daha olumlu benlik algısı geliştirdikleri sonucuna ulaşmıştır. Altun ve Yazıcı (2013) ise çalışmalarının sonucunda akademik başarının benlik algısını anlamlı şekilde yordadığını belirtmiştir.

Bütün bunlar ergenlerde benlik imgesinin gelişmesine ve bireylerin bu imgeye bağlı olarak bir takım tutumlar sergilediğine işaret etmektedir. Örneğin bu konuda Ziglar (2005), insanların iş hayatında, okulda ve ilişkilerinde yaşadıklarını olumlu ya da olumsuz olarak şekillendiren etkenin kişinin kendilik imgesi olduğu görüşünü savunmaktadır. Bu bağlamda ergenlik döneminde öğrencilerde gelişen kendilik imgesinin okul başarısına etki edip etmediği, aralarında bir ilişki olup olmadığı ise eğitim-öğretim açısından ışı tutulması gereken bir konudur. Bu çalışmayla, lise öğrencilerinin kendilik imgelerinin okul başarılarına nasıl bir etki ettiği ele alınacak ve bu sayede okul başarılarını artırma adına bazı ipuçları elde edilmeye çalışılacaktır.

\section{Yöntem}

\section{Araştırma modeli}

Bu çalışmada nicel araştırma modellerinden betimsel araştırma modeli uygulamıştır. "Betimsel araştırmalar mevcut olayların daha önceki olay ve koşullarla ilişkilerini dikkate alarak, durumlar arasındaki etkileşimi açıklamaya çalışan, olayların, objelerin, varlıkların, kurumların, grupların 
ve çeşitli alanların ne olduğunu betimleyen araştırmalardır” (Kaptan, 1995, s. 59). Araştırma bu bağlamda, ergenlerde benlik imgesi ve okul başarısı arasında ne gibi bir ilişki olabileceğini ve benlik imgesinin okul başarısına ne derece etki ettiğini ortaya çıkarmayı amaçlamıştır.

\section{Evren ve örneklem}

Araştırmanın evrenini, Devrek ilçesindeki lise öğrencileri oluşturmaktadır, örneklemi ise random yoluyla seçilen iki farklı liseye devam eden öğrencilerdir. Araştırma bu okullarda, 20122013 eğitim-öğretim yılı güz dönemi, 9-10-11. sınıflarında okuyan 50 kız, 73 erkek, toplam 123 öğrencinin katılımıyla gerçekleştirilmiştir. Ergenlerdeki benlik imgesi ve ders başarıları arasında anlamlı bir ilişki olup olmadığı, bu öğrencilere verilen 99 soruluk bir anketle karşılaştırmalı olarak incelenmiştir.

\section{Veri toplama araçları}

Araştırmacı tarafından hazırlanan sosyo-demografik veri anketi ile öğrencilerin cinsiyet, yaş, aylık gelir ve bir önceki dönem okul not ortalamaları gibi özellikleri belirlenmiştir. Kendilik imgesi ile okul başarısı arasındaki ilişki incelenirken öğrencilerin not ortalamaları okul başarılarını temsil etmektedir. Ayrıca verilerinin toplanmasında öğrencilerin benlik imgeleri hakkında bilgi edinebilmek için "Offer Kendilik İmgesi Ölçeği” kullanılmıştır. Offer ve Howard tarafından (1982) geliştirilen bu ölçek Çuhadaroğlu Çetin tarafından Türkçe olarak geçerlik ve güvenirlik çalışması gerçekleştirilerek düzenlenmiştir.

Offer Kendilik İmgesi Ölçeği: Daha çok ergenlerin kendilik imgelerini ölçmek için kullanılan ve yüksek bir geçerlilik ve tutarlılığa sahip bu test, farklı konular üzerinde kişinin tutumunu ve hislerini açığa çıkarmaya yarayan negatif ve pozitif maddelerden oluşur. Bu ölçek 99 sorudan ve 10 alt ölçekten oluşmaktadır. Ölçeğin alt boyutları ve bunların özellikleri sırasıyla şu şekildedir:

a) Aile ilişkileri: Ergenin ailesine ilişkin duyguları ile ilgilidir. Bu alt ölçek aynı zamanda bireyin yaşadığ

b) Dürtü kontrolü: Bu gruptaki sorular bireyin iç ve dış çevredeki baskılara karşı direnmede, egosunun ne ölçüde güçlü olduğunu çıkarmayı amaçlamaktadır.

c) Cinsel tutumlar: Bu alt ölçek bireyin cinsel konulardaki duyguları, tutumları ve davranışları ele alınmakta, karşı cinsle ilişkileri hakkında bilgi edinilmektedir.

d) Bireysel değerler: Bu alt ölçekteki sorular, bireyin davranışlarında, kendini mi yoksa başkalarını mı merkeze aldığı ile ilişkilidir.

e) Beden imgesi: Bireyin kendi bedenine karşı olumlu ve olumsuz duyguları ele alınmaktadır.

f) Duygusal düzey: Bireyin ruhsal yapısı içindeki duygusal uyumu ölçülmektedir.

g) Çevre uyumu: Bireyin baş etme yeteneği hakkında ne hissettiği ile ilgilidir.

h) Meslek ve eğitim hedefleri: Bu alt ölçekteki sorular, bireyin mesleğe hazırlığını, gelecekle ilgili planlarını ve genel olarak çalışma ve iş konusundaki tutumlarını ölçmektir. 
i) Sosyal ilişkiler: Bireyin arkadaşlarının niteliği ve yaşıt gruplarıyla ilişkileri hakkında bilgi vermektedir.

j) Ruh sağlı̆̆ı: Bu ölçek, bireyin açık psikolojik belirtilerinin olup olmadığını gösterir.

Farklı örneklemlerle ilgili yapılan yapı geçerliği çalışmalarında ölçeğin alt ölçekleri arasındaki korelasyonun .26 ile .61 arasında değiştiği gözlenmiştir. Ölçeğin, bireysel değerler alt ölçeği dışındaki boyutları yeterli iç tutarlılığa (güvenirliğe) sahiptir.

\section{Verilerin toplanması}

Belirlenen okullar ziyaret edilmiş, sınıf öğretmenleriyle görüşülmüştür. Gerekli açıklamalar yapıldıktan sonra katılımcılara Offer Kendilik İmgesi Anketi ve araştırmacı tarafından hazırlanan sosyo-demografik veri anketi ve uygulanmıştır. Öğrencilere, 99 sorudan oluşan 5’li likert tipi anketin doldurulması için 45 dakika zaman verilmiştir.

\section{Verilerin analizi}

Araştırma verilerinin analizinde, ilk olarak Kolmogorov-Simirnov testi ile sürekli değişkenlerin normal dağılıp dağılmadığı belirlenmiştir. Tüm sürekli değişkenlerin normal dağılım gösterdiği tespit edilmiştir. Daha sonra iki grup ortalamalarını karşılaştırmak için bağımsız t testi, ikiden fazla grup ortalamalarını karşılaştırmak için ise Tek Yönlü Varyans analizi uygulanmıştır. Tek Yönlü Varyans analizinde gruplar arasında ortaya çıkan farkı değerlendirmek için Bonferroni Çoklu Karşılaştırma testi uygulanmıştır. Sürekli değişkenlerin not ortalaması ile ilişkisini ortaya koymak için ise Pearson momentler çarpımı korelasyon analizi yapılmıştır. Son olarak not ortalaması ile anlamlı ilişkisi olan değişkenlerin not ortalamaları üzerindeki etkisini görmek için çoklu doğrusal Regresyon analizi uygulanmıştır. Regresyon analizinde cinsiyet kukla (dummy) değişken olarak alınmıştır. Verilerin anlaşılır olması ve kolay yorumlanabilmesi için bulgular tablolar halinde sunulmuştur.

\section{Bulgular}

Ergenlerdeki okul başarısı ile kendilik imgesi arasında ilişkiyi incelemek için, okul başarısını temsil eden not ortalamaları ile on faktörlü kendilik imgesi ölçeği karşılaştırılmıştır. Bunun sonucunda bireysel değerler (BD) (.031) ile meslek ve eğitim hedeflerinin (ME) ( $\mathrm{p}<.001)$ okul başarısı ile arasında istatistiksel olarak anlamlı bir ilişki görülmüştür. Bunun haricinde, not ortalamasını etkileyebileceği düşünülen diğer değişkenlerden Yaş (.004) ve haftalık ders çalışma saati (.014) ile okul başarısı arasında da anlamlı bir ilişki bulunmuştur (Bkz. Tablo 3). 
Tablo 1

\section{Katıımaların Tanımlayıa Özellikleri}

\begin{tabular}{|l|c|}
\hline Cinsiyet (Kız/Erkek) & $50 / 73$ \\
\hline Yaş (Ortalama \pm standart sapma) & $1598 \pm 0.91$ \\
\hline Not ortalaması (Ortalama \pm standart sapma) & $3.06 \pm 0.68$ \\
\hline Aylık gelir (TL) & $1085.60 \pm 565.99$ \\
\hline Sınıf (9/10/11) & $53 / 41 / 29$ \\
\hline Kardeş varlığı (Var/Yok) & $116 / 7$ \\
\hline Kendine ait oda (Var/Yok) & $87 / 30$ \\
\hline Sınıf tekrarı (Evet/Hayır) & $6 / 117$ \\
\hline Evde bilgisayar varlığı (Var/Yok) & $76 / 47$ \\
\hline
\end{tabular}

T-test sonucu cinsiyete göre ortalamalar karşılaştırıldığında, haftalık ders çalışma süresi (.033), not ortalaması (<.001), cinsel tutum (CT) (<.001), bireysel değerler (BD) (.004), çevre uyumu (CU) (.037) ve meslek ve eğitim hedefleri (ME) (<.001) değişkenleri ile cinsiyetler arasında anlamlı farklılık olduğu görülmüştür. Kızların haftalık ders çalışma süreleri, not ortalamaları, bireysel değer algıları, çevre uyumu ve meslek ve eğitim hedefleri, erkeklere göre daha yüksektir (Tablo 2). Bunun yanında cinsel tutum değişkeni açısından ise erkekler kızlara göre daha olumlu bir tutuma sahiptir.

Tablo 2

Çalışma Verilerinin Ortalamalarının Cinsiyetlere Göre Karşılaştırılması

\begin{tabular}{|c|c|c|c|c|c|}
\hline & \multicolumn{2}{|c|}{ K1z (sayı =50) } & \multicolumn{2}{|c|}{ Erkek $($ sayı $=73)$} & \multirow{2}{*}{ p değeri } \\
\hline & Ortalama & Standart sapma & Ortalama & Standart sapma & \\
\hline $\begin{array}{l}\text { Ders çalışma süresi } \\
\text { (saat/hafta) }\end{array}$ & 2.83 & 0.974 & 2.35 & 1.30 & .033 \\
\hline Not ortalaması (5) & 3.36 & 0.707 & 2.86 & 0.58 & $<.001$ \\
\hline Aylık gelir & 1219.43 & 615.37 & 1003.42 & 522.09 & .075 \\
\hline Uyku süresi (saat/gün) & 7.91 & 1.88 & 7.646 & 1.47 & .381 \\
\hline Aİ & 32.14 & 2.515 & 32.38 & 2.86 & .627 \\
\hline DK & 26.16 & 6.61 & 27.57 & 7.20 & .271 \\
\hline $\mathrm{CT}$ & 20.58 & 8.13 & 26.67 & 8.20 & $<.001$ \\
\hline $\mathrm{BD}$ & 31.28 & 4.04 & 28.60 & 5.45 & .004 \\
\hline Bİ & 38.64 & 5.38 & 38.18 & 6.95 & .696 \\
\hline $\mathrm{DD}$ & 38.30 & 11.08 & 39.63 & 8.87 & .463 \\
\hline $\mathrm{CU}$ & 52.36 & 6.69 & 49.36 & 8.35 & .037 \\
\hline $\mathrm{ME}$ & 39.22 & 2.91 & 36.53 & 4.66 & $<.001$ \\
\hline Sİ & 43.86 & 7.61 & 42.76 & 7.92 & .447 \\
\hline RS & 43.50 & 8.78 & 44.72 & 8.10 & .436 \\
\hline
\end{tabular}

Aİ: Aile ilişskileri; DK: Dürtü kontrolü; CT: Cinsel tutum; BD: Bireysel değerler; Bİ: Beden imgesi; DD: Duygusal düzey; CU: Çevre uyumu; ME: Meslek ve eğitim hedefleri; Sİ: Sosyal ilişkiler; RS: Ruh sağlığı 
Regresyon analizi sonuçlarına göre öğrencilerin not ortalamalarına, cinsiyet ( $\mathrm{r}:$.247; $\mathrm{p}<0.05)$, yaş ( $\mathrm{r}$. .178; p<0.05) ve meslek ve eğitim hedefleri (ME) ( $\mathrm{r}: .225 ; \mathrm{p}<0.05)$ faktörlerinin bağımsız olarak etki ettiği görülmüştür (Tablo 4). Standardize edilmiş regresyon katsayısına göre, yordayıcı değişkenlerin okul başarısı üzerindeki göreli önem sırası; cinsiyet $(\beta=.25)$, meslek ve eğitim hedefleri $(\beta=.23)$ ve yaştır $(\beta=.18)$.

\section{Tablo 3}

Not Ortalaması Ille Sosyo-demografik Özellikler ve OKI Alt Ölçekleri Arasındaki Korelasyon

\begin{tabular}{|l|c|c|}
\hline & Not ortalaması & p değeri \\
\hline Yaş & .256 &. $\mathbf{0 0 4}$ \\
\hline Kardeş sayısı & -.146 & .117 \\
\hline Aylık gelir & -.062 & .559 \\
\hline Ders çalışma süresi & .227 &. $\mathbf{0 1 4}$ \\
\hline Uyku süresi & .069 & .453 \\
\hline Aİ & .128 & .159 \\
\hline DK & -.037 & .687 \\
\hline CT & -.116 & .201 \\
\hline BD & .196 & .031 \\
\hline Bİ & .080 & .381 \\
\hline DD & .049 & .588 \\
\hline CU & .139 & .127 \\
\hline ME & .391 & $<.001$ \\
\hline Sİ & -.122 & .181 \\
\hline RS & -.167 & .069 \\
\hline $\begin{array}{l}\text { Aİ: Aile ilişkileri; DK: Dürtü kontrolü; CT: Cinsel tutum; BD: Bireysel değerler; Bi்: Beden } \\
\text { imgesi; DD: Duygusal düzey; CU: Çevre uyumu; ME: Meslek ve eğitim hedefleri; Sİ; Sosyal } \\
\text { ilişkiler; RS: Ruh sağlığı }\end{array}$ & & \\
\hline
\end{tabular}

Öğrencilerden evinde bilgisayar olanlarla olmayanlar arasında okul başarısı ve haftalık ders çalışma süresi bakımından istatistiksel olarak fark olmadığı gözlenmiştir. Ayrıca, öğrencilerden kendine ait odası olanlarla olmayanlar arasında da okul başarısı ve haftalık ders çalışma süresi açısından istatistiksel olarak anlamlı bir fark görülmemiştir.

Sınıflara göre haftalık ders çalışma süresi ve not ortalaması ortalamaları karşılaştırıldığında sınıfların not ortalaması açısından farklılık gösterdiği $(\mathrm{p}=.003)$, ders çalışma ortalaması açısından ise farklı olmadığ $(\mathrm{p}=.326)$ bulunmuştur. Bonferroni çoklu karşılaştırma analizi sonucunda ise sinıflar arasında not ortalamaları bakımından farklılığın sadece 9. sinıflar ile 11. sinıflar arasında olduğu tespit edilmiştir ( $\mathrm{p}=.003)$. 
Tablo 4

Not Ortalamasına Etkisi Olan Etkenlerin Çoklu Doğrusal Regresyon Analizi lle Değerlendirilmesi

\begin{tabular}{|l|c|c|c|c|}
\hline & $\beta$ & $\mathrm{t}$ & $\mathrm{p}$ & $\mathrm{r}$ \\
\hline Cinsiyet & -.247 & -2.797 & $\mathbf{. 0 0 6}$ &. $\mathbf{2 4 7}$ \\
\hline Yaş & .178 & 2.076 & $\mathbf{. 0 4 0}$ & $\mathbf{. 1 7 8}$ \\
\hline Haftalık ders çalışma saati & .134 & 1.530 & .129 & .051 \\
\hline BD & -.052 & 0.581 & .562 & .012 \\
\hline ME & .225 & 2.343 & $\mathbf{. 0 2 1}$ & .225 \\
\hline $\begin{array}{l}\text { BD: Bireysel değerler; ME: } \\
\text { Meslek ve eğitim hedefleri }\end{array}$ & & & & \\
\hline
\end{tabular}

\section{Tartışma}

Bu çalışmada ergenlerde kendilik imgesi (benlik imgesi) ile okul başarısı arasında bir ilişki olup olmadığı ve buna bağlı olarak kendilik imgesinin okul başarısına nasıl bir etki ettiği incelenmiştir. En önemli ilişkinin kendilik imgesi faktörlerinden mesleki ve eğitsel hedefler ile okul başarısı arasında olduğu tespit edilmiştir. Mesleki ve eğitsel hedefler okul başarısını anlamlı düzeyde etkilemektedir. Sarigiani ve arkadaşları (1990), yaptıkları benzer bir çalışmada ergenlerin gelecek adına eğitim planlarıyla okul başarıları arasında anlamlı bir ilişki olduğunu ileri sürmüşlerdir. Buna ek olarak ergenler arasında düşük mesleki ve eğitimsel hedefleri olanların düşük kendilik imgesine sahip olduklarını belirtmişlerdir. Bir diğer araştırmada Hall ve Hall (1976) öğrencilerin gelecekle ilgili hedeflerinin akademik başarıyla ilişkisini okul desteği alan ve almayan öğrencilerle kıyaslamış ve yüksek düzeyde okul desteği alan öğrencilerde eğitim hedeflerinin başarıyı tetiklediği, düşük düzeyde okul desteği alan öğrencilerde ise benlik imgesinin başarıyı tetiklediğini savunmuşlardır. Kaplan ve Maehr (1999) de çalışmalarında, pozitif benlik imgesine sahip bireylerin gelecek adına yüksek idealler taşıdığına değinmişlerdir. Bütün bunlar dikkate alındığında mesleki ve eğitsel bir hedefe sahip öğrencilerin hedefe dayalı bir motivasyon kazanarak okul başarılarının arttığı düşünülebilir. Bandura (1997) motivasyon teorilerinden hedef teorisini, kişiyi kendine koyduğu hedefler ve onlara ulaşmakla elde ettiği öz yeterlilik duygusunun motive edeceği şeklinde açıllamıştır.

Rosenberg ve arkadaşları (1989), akademik başarı ve kendilik imgesi arasında anlamlı bir ilişki olduğunu, akademik başarının kendilik imgesinin etkileme düzeyinin, kendilik imgesinin akademik başarıyı etkileme düzeyinden daha düşük olduğunu saptamışlardır. Ayrıca Cheung (1986) yapmış olduğu çalışmada yüksek benlik imgesi puanına sahip öğrencilerin okul başarılarını, düşük ve orta düzeyde benlik imgesi puanına sahip öğrencilerin okul başarılarından anlamlı şekilde yüksek bulmuştur. Gaspard ve Bernett (1991) de yapmış oldukları çalışmada kendilik imgesi ve akademik başarı arasındaki ilişkiyi anlamlı olarak değerlendirmişlerdir. 
Araştırmadaki diğer bir sonuç, kız ve erkek öğrencilerin okul başarılarının birbirinden farklı olduğudur. Bulgulara göre kız öğrencilerin okul başarısı erkek öğrencilerden yüksektir. Aynı zamanda okul başarısı yüksek olan kız öğrencilerin mesleki ve eğitim hedefleri de erkek öğrencilere göre daha yüksektir. Roberts ve Petersen (1992), yaptıkları araştırmada matematik dersi başarısı yüksek olan kız öğrencilerin kendilik imgesinin daha olumlu olduğunu gösterirken erkeklerde ders başarısı düşük olanların da olumlu kendilik imgesine sahip olduklarını tespit etmişlerdir. Buna ek olarak, Roberts ve arkadaşları (1990), erken ergenlik dönemindeki kız ve erkek öğrencilerin akademik başarıları ve benlik imgeleri arasındaki ilişkiyi incelemiştir. Bunun sonucunda 6. sınıftan 7. sınıfa geçen kızlarda, benlik imgesi ve okul başarısı ilişkisi zayıflarken erkeklerde arttığı; 7. sınıftan 8. sınıfa geçen kız öğrencilerde bu ilişkinin tekrar arttığ fakat erkeklerde değişmediği sonucuna varmışlardır. Bacchini ve Magliulo (2003) ise düz lise ve meslek lisesinde okuyan öğrenciler üzerindeki araştırmasında meslek liseli erkeklerin kızlara ve düz liseli öğrencilere göre daha olumlu kendilik imgesine sahip olduğunu belirtmiştir.

Bazı çalışmalar ise kendilik imgesi ve akademik başarının birbirini olumlu ya da olumsuz etkilemediğini savunmuştur. Hart (1985) yapmış olduğu çalışmada akademik başarı ve kendilik imgesi arasında anlamlı ilişki bulamamıştır. Öner (1982) de aynı şekilde, öğrencilerin benlik imgeleri ile akademik başarıları arasında anlamlı bir ilişki olmadığını ileri sürmüştür. Newman and Richard'a (1997) göre benlik kavramının okul başarısı üzerinde olumlu ya da olumsuz etkisi yoktur. Tam tersine okul başarısı düşük öğrenciler bu durumu bastırması adına daha olumlu benlik imgesine sahiptirler. Cheung (1986) kızlar ve erkekler arasında yaptığı karşılaştırmada erkeklerin benlik imgesi düzeyleri ile okul başarıları arasındaki ilişkiyi kızlara oranla daha yüksek bulunmuştur. Buna göre bu çalışmanın bulgularının aksine kızların benlik imgesi düzeyi, erkeklerin benlik imgesi düzeyine göre akademik başarıyı daha az etkilemektedir. Sonuçların bu şekilde farklılaşması kendilik imgesi algısında sosyokültürel farklılıkların etkili olabileceğini akla getirmektedir. Türkiye’de hala okula gönderilmeyen kız çocuklarının varlığı düşünüldügünde (Caner ve diğerleri, 2015) aile baskısını daha çok hisseden Türk kız çocuklarının, yüksek mesleki hedeflerle yüksek başarı yakalayıp bireysel özgürlük kazanma isteği bu sonucu ortaya çıkarmış olabilir.

Çalışmanın sonunda, lise öğrencileri üzerinde kendilik imgesi ile okul başarısı arasında, kendilik imgesi faktörlerinden "Meslek ve Eğitim Hedefleri (ME)" ve "Bireysel Değerler (BD)" ile okul başarısı arasında anlamlı bir ilişki olduğu görülmüştür. Meslek ve eğitim hedeflerinin ise diğer değişkenlerden bağımsız olarak okul başarısına önemli ölçüde etki ettiği saptanmıştır.

Bunun haricinde, diğer değişkenlerden cinsiyetin okul başarısına etkisine bakıldığında, cinsiyete göre okul başarısının farklılık arz ettiği saptanmıştır. Kız öğrencilerin erkek öğrencilere göre daha başarılı olduğu tespit edilmiştir. Bulgulara bakıldığında, erkek öğrencilere göre okul başarıları daha yüksek olan kız öğrencilerin aynı zamanda ME (Meslek ve Eğitim Hedefleri)'nin de erkek öğrencilere göre daha yüksek olduğu tespit edilmiştir.

Çalışma bulguları doğrultusunda, eğitmenlerin lise öğrencilerinde okul başarısını yükseltmek adına, öğrencilerin meslek ve eğitim hedeflerini dikkate almaları önerilmektedir. Bu bağlamda 
öğrencilerin meslek ve eğitim hedeflerini yükseltmek amacıyla çeşitli rehberlik çalışmaları yapılabilir. Örneğin, okul rehberlik servisi ve sınıf öğretmenleri meslek tanıtım günleri düzenleyebilir ya da çeşitli meslekler kendi çalışma alanlarında gözlemlenerek uzmanlarından bilgiler alınabilir. Bunun yanında her öğrencinin yetenekleri tespit edilerek kişiye uygun mesleklerin seçilmesi ve bu yönde kişiye özel bir motivasyon sağlanabilir. Bütün bunlar dikkate alındığında, hem sınıf öğretmenleri, hem okul rehberlik ve psikolojik danışmanları hem de okul idarecilerine büyük sorumluluklar düştüğü görülmektedir.

Çalışmanın eğitim-öğretime katkı sağlayabilmesi adına, farklı bölgelerde, daha fazla sayıda lise öğrencisi ile gerçekleştirilmesi önerilmektedir. Farklı bölgelerde yapılması, meslek ve eğitim hedefleri ile okul başarısı ilişkisinde kültürel farklılıktan kaynaklanabilecek etkilerin belirlenmesini sağlayabilir. Ayrıca aynı çalışma, ilköğretim ikinci kademe öğrencileri üzerinde de gerçekleştirilerek daha kapsamlı hale getirilebilir. Çalışmanın ilköğretimde yapılması meslek ve eğitim hedeflerinin erken dönemde belirlenmesinin önemini ortaya çıkarabilir. 


\section{Kaynaklar}

Adams, J. F. (1995). Ergenliği anlama. (B. Onur, Çev.). Ankara: İmge Yayıncılık.

Altun, F. ve Yazıcı, H. (2013). Ergenlerin benlik algılarının yordayıcıları olarak: akademik öz-yeterlik inancı ve akademik başarı. Kastamonu Eğitim Dergisi, 21(1), 145-156.

Bacchini, D. \& Magliulo, F. (2003). Self-1mage and perceived self-efficacy during adolescence. Journal of Youth and Adolescence, 32(5), 337-349.

Bogenç, A. (1998). Grupla psikolojik danışmanın suçlu gençlerin kendine saygı düzenlerine etkisi. (Yayınlanmamış doktora tezi). Ankara Üniversitesi, Ankara.

Bandura, A. (1997). Self-efficacy: The exercise of control. New York, NY: Freeman.

Burns, R. B. (1979). Attitudes to self and attitudes to others. British Journal of Social and Clinical Psychology, $15,319-321$.

Caner, A., Guven, C., Okten, C. \& Sakalli, S.O. (2015). Gender roles and the education gender gap in Turkey. Social Indicators Research, 1-24.

Cheung, T.S. (1986). Sex differences in the effect of academic achievement of self- esteem. A Hong Kong Case. Social Behavior and Personality, 2(14), 161-165.

Çetin, F. Ç. \& diğerleri. (2010). Attachment styles and self-image in Turkish adolescents. Journal of Research on Adolescence, 20(4), 840-848.

Çetin, F. Ç. ve Ulay, H. T. (2011). Effects of Self-image on ıdendity status among Turkish adolescents. Adolescent Psychiatry, 1, 88-93.

Damon, W., \& Hart, D. (1988). Self-understanding in childhood and adolescence. New York: Cambridge University Press.

Demiriz, S. \& Öğretir, A. D. (2007). Alt ve üst sosyo-ekonomik düzeydeki 10 yaş çocuklarının anne tutumlarının incelenmesi. Kastamonu Eğitim Dergisi, 15(1), 105-122.

Gaspard, M. R. \& Bernett, M. F. (1991). The relationship between self esteem and academic achievement of rural grade students. Journal of Rural and Small Schools, 2-9.

Gender, J. M. \& Harry, W. G. (1993). Çocuk ve ergen gelişimi. (B. Onur Çev.). Ankara: İmge Yayıncılık.

Hall, D. T. \& Hall, F. S. (1976). The relationship between goals, performance, success, self-image, and involvement under different organization climates. Journal of Vocational Behavior, 9(3), 267-278.

Hart, J. G. (1985). Lawseq: Its relation to other measures of self-esteem and academic ability. Research Notes, Br. J. Educ. Pschol, 55, 167-169.

Hauser, S. T. \& Shapiro, R. L. (1973). Differentiation of adolescent selfimages. Archives of General Psychiatr, 29, 63-68.

Hauser, S. T. (1976). The content and structure of adolescent self-images. Longitudinal studies. Archives of General Psychiatry, 33, 27-23.

Kaplan, A. \& Maehrb, M. L. (1999). Achievement goals and student well-being. Contemporary Educational Psychology, 24(4), 330-358.

Kaptan, S. (1995). Bilimsel araştırma ve istatistik teknikleri, 10. Baskı, Ankara: Rehber Yayınevi.

Kuzgun, Y. (1985). Adwards Kişisel Tercih Envanterinin Türkiye'de geçerlilik ve güvenirliği. A.Ü. Eğitim Bilimleri Fakültesi Dergisi, 17, 69-85.

Newman, L. S. \& Richard, W. F. (1997). When stakes are higher: Self-esteem instability and self-handicapping. Journal of Social Behavior \& Personality, 12(1), 217-232.

Loeb, R. C. \& Jay, G. (1987). Self-concept in gifted children: Differential impact in boys and girls, Gifted Child Quarterly, 31, 9-14.

Offer, D., Ostrov E., \& Howard K. I. (1981). The adolescent: A psychological self-portrait. New York: Basic Books. 
Offer, D., Ostrov, E. \& Howard, K. I. (1982). The Offer Self-Image Questionnarier for adolescents: A Manuel. (3rd. Ed.), Chicago: Michael Reese Hospital.

Offer, D., Ostrov, E., \& Howard, K. I. (1984). The self-image of normal adolescents. New Directions in Mental Health Service, 22, 5-17.

Offer, D., Ostrov, E., Howard, K. I., \& Dolan, S. (1992). Manual for offer self-image questionnaire, revised. Los Angeles, CA: Western Psychological Services.

Öner, U. (1982). Benlik kavramı ile mesleki benlik kavramı arasındaki farkın akademik başarı ile ilişkisi. (Yayınlanmamış doktora tezi). Ankara Üniversitesi, Sosyal Bilimler Enstitüsü, Ankara.

Özoğlu, S. Ç. (1976). Psikolojik danışmada benlik kavram. Ankara Üniversitesi Eğitim Bilimleri Fakültesi Dergisi, 8, 1-4.

Paglieri, F. (2012). Consciousness in interaction: The role of the natural and social context in shaping consciousness. USA: John Benjamins Publishing Company.

Roberts, L. R. \& Petersen, A. C. (1992). The Relationship between academic achievement and social selfimage during early adolescence. The Journal of Early Adolescence, 12(2), 197-219.

Roberts, L. R. ve diğerleri. (1990). Gender differences in the relationship between achievement and self1mage during early adolescence. The Journal of Early Adolescence, 10(2), 159-175.

Rosenber, M., Schooler, C. \& Schoenbach, C. (1989). Self-esteem and adolescent problems: modeling reciprocal effects. American Sociological Review, 54(6), 1004-1018.

Sarigiani, P. A. ve diğerleri. (1990). Self-Image and educational plans of adolescents from two contrasting communities. The Journal of Early Adolescence, 10(1), 37-55.

Şekercioğlu, G. \& Güzeller, C. O. (2012). Ergenler için benlik algısı profilinin faktör yapısının yeniden değerlendirilmesi. Bilig, 60, 215-236.

Zeidner, M. \& Schleyer, E. J. (1998). The Big-Fish-Little-Pond Effect for Academic Self-Concept, Test Anxiety, and School Grades in Gifted Children. Contemporary Educational Psychology, 24, 305329.

Ziglar, Z. (2005). Success and the self-image. New York: Nightingale Conant Production. 